\title{
THE IMPACT OF LAND MARKET PROCESSES ON THE POOR IN RURAL VIETNAM
}

\author{
${ }^{1}$ W. Smith, ${ }^{2}$ I. Williamson, ${ }^{3}$ A. Burns, ${ }^{4}$ Tran Kim Chung, \\ ${ }^{5}$ Nguyen Thi Vinh Ha, ${ }^{6}$ Hoang Xuan Quyen, \\ ${ }^{1} 13$ Tran Hung Dao, Hanoi, Vietnam \\ ${ }^{2}$ Department of Geomatics, The University of Melbourne, Victoria 3010, Australia \\ ${ }^{3}$ Land Equity International Pty. Ltd.,Wollongong, New South Wales 2500, Australia \\ ${ }^{4}$ Central Institute of Economic Management, 68 Phan Dinh Phung, Hanoi, Vietnam \\ ${ }^{5}$ Mekong Economics Ltd.,24 Tran Vu, Hanoi, Vietnam \\ ${ }^{6}$ Centre for Rural Progress, 38b Trieu Viet Vuong, Hanoi, Vietnam
}

\begin{abstract}
This paper examines the link between formal land tenure and poverty alleviation in the context of rural Vietnam. It assesses the relevance of the ideas of Hernando de Soto through the documentation of both formal and informal land market processes in order to identify efficiencies.

The findings suggest that Vietnam has made significant progress in extending formal land use rights to agricultural land. However, obstacles remain in the issue of title on rural residential land, including high land use levies, costs of converting garden to residential land, surveying costs and the skills of cadastral officials.

Transactions in agricultural land increasingly take place within the formal sector. In general, land sales and mortgages are processed quickly and at low cost by land administration authorities. However, evidence was found of informal fees, requirements for extra documentation, inconsistent land valuation procedures and government intervention to prevent sale of small plots.

Where informality survives in the land market, examples were found of its detrimental effects, particularly on poor households: ownership disputes, reduced land values and difficulties in mortgaging informally held land. However, the Vietnamese evidence hints that the 'transforming effects' of formal title can also be exaggerated. Formal land title can cause its own difficulties when plot measurement is poorly executed and boundary disputes arise. The decisive role of formal title in facilitating mortgages is also questionable when banks accept other types of land document and the mechanisms for foreclosure remain complicated.

Overall the research suggests that poor people may benefit more from efficient, inclusive and low cost formal land administration systems than from attempts to protect them from market forces. A series of recommendations are put forward to improve Vietnam's land administration system as the new 2003 Land Law is implemented.
\end{abstract}

KEYWORDS: Poverty. Land tenure. Vietnam. Land title-formal. Land title-informal

\section{INTRODUCTION}

The approach adopted in this research was inspired by the popular theory of how land market processes impact on the poor outlined by Hernando de Soto in his book 'The Mystery of Capital: Why Capitalism Triumphs in the West and Fails Everywhere Else' [1]. It also draws on the work of Wallace and Williamson [4] in understanding the operation and evolution of land markets. De Soto argues that the poor are often unable to reap maximum economic benefit from land assets which remain hidden within the informal sector. Until the poor receive formal, legal title for the land they occupy, their assets remain essentially 'dead' capital. The extension of formal land title is proposed as a vital determinant of economic growth and poverty reduction.

Contact: I Williamson. e-mail: ianpw@unimelb.edu.au

(C) 2007 Survey Review Ltd. 
De Soto outlines a number of reasons why, in some countries, the poor have been unable to secure formal title for their land assets, including exclusion from the legal process by elites, extreme complication of formalisation procedures and the high costs of undertaking these processes. In the Philippines, for example, De Soto claims that legal purchase of a settlement on state or private land through state housing programmes requires 168 steps involving 53 state and private organisations and takes from 13 to 25 years. If that land is categorised as agricultural, additional steps for conversion to residential use take two more years [1]. A variety of similar examples are given from Egypt, Haiti and Peru. Difficulties of this kind clearly force poor households into informal land markets.

De Soto estimates the volume of 'dead capital' held by the poor at 9.3 trillion USD globally and identifies six ways in which formal land title and land administration systems can transform the value of land assets to the benefit of the poor and of society in general:

a. Formal land titles have an abstract economic value, valid in a wide range of contexts, which untitled physical assets alone cannot have. ("Fixing the economic potential of assets").

b. With a national system of formal land title, economic value implicit within land title has generic worth recognised consistently throughout society. ("Integrating dispersed information into one system.")

c. Formal title gives landholders legal protection to their land rights from the state but, due to legal mechanisms for forfeiture of title, also creates pressure to honour commitments ("Making people accountable").

d. As formal title signifies the abstract economic value of land, more flexible use of assets is possible - e.g. issuing shares in property, using property to gain access to capital ("Making assets freely exchangeable").

e. Formal property systems join land users into networks through which their assets can be assembled into more valuable combinations ("Networking people").

f. In addition to protecting ownership, formal land title systems which record and register transactions give greater confidence to parties seeking to participate in the market. ("Protecting transactions")

De Soto's argument has been subject to considerable criticism. In particular, the dangers and disadvantages of informality have been questioned. It has been argued that formal tenure may not necessarily be more secure than informal tenure, while transfer and rental markets in untitled land are often vibrant [3]. Moreover, the transforming effects of land title formalisation programmes have also been questioned by some [2]. Land titling has not always led to a widening of opportunities for poor people in financial markets. Public investment in urban infrastructure, upgrading and social programmes may have more effect on informal settlements than titling.

In relation to de Soto's thesis, this research project was designed to examine:

a. The extent to which the 'problem' of informality posed by de Soto is significant in rural Vietnam.

b. The reasons why poor people may currently be excluded from formal land title and land markets.

c. Evidence for the benefits of inclusion in the formal land market and the disadvantages and costs to the poor of continued informality.

In order to answer these questions, the research methodology focused on two main activities: 
- Documenting both formal and informal land use market processes (allocation, transfer, lease and mortgaging of land use rights) as suggested by de Soto.

- Determining the quality of the recorded government land records (owner of land use rights, land use, diagram and boundaries, mortgage or restriction on land use parcel) with the actual situation on the ground."

It was decided to restrict the examination of land processes and records to lowland, rural areas where a high proportion of land use certificates have already been issued. The rural focus was justified by the concentration of poverty in Vietnam in the countryside ( $90 \%$ of Vietnam's poor are estimated to live in rural areas), while the lowland focus was justified by the more advanced state of land market development compared with the highlands. The research, therefore, concentrates on agricultural and rural residential land, rather than forestry or urban land.

The investigation of market processes and land market data was also designed to lead to practical recommendations to the Ministry of Natural Resources and the Environment (MONRE) on how to prevent exclusion of poor people from the formal land market and how to maximise the benefits of formal land use title for poor households. These recommendations are of particular significance with the issue of the 2003 Land Law (13/2003-QH-11) which came into effect on $1^{\text {st }}$ July 2004, together with a series of decrees and circulars on implementation of the Land Law which were signed by the Prime Minister and Minister of Natural Resources and the Environment in October and November 2004.

The project objectives were therefore formulated as follows:

"To undertake research to assess how the operation of the emerging land use market in Vietnam impacts the poor with particular emphasis on the implementation and impact of the current Land Law and the new Land Law, resulting in recommendations for policy development or interventions in the land administration system to maximise their positive impact on the poor."

This research on the impact of land market processes on the poor was conducted as part of the Asian Development Bank's 'Making Markets Work Better for the Poor' project $^{1}$ (MMWBP). MMWBP is a three year research project covering Vietnam, Laos and Cambodia. The project conducts analytical work focused on the functioning of markets and the extent to which the poor are able to benefit from them. It also builds capacity to support pro-poor market development through networking and the promotion of policy dialogue.

\section{BACKGROUND TO LAND TENURE ISSUES IN VIETNAM}

Before describing the research methods and results, it may be helpful to present an overview of the development and main features of Vietnam's land tenure system.

Vietnam's current land tenure system is rooted in a fifty year history of revolutionary upheaval, land reform, central planning and collectivisation. In contrast to many other countries in Southeast Asia, the control of landlords and colonial plantation owners over land in North Vietnam was broken during the period of anti-colonial resistance and land reform in the 1940s and 1950s. Land reform in the North, however, was

\footnotetext{
${ }^{1}$ Information on this project is available on the project website (http://www.markets4poor.org)
} 
followed swiftly by the collectivisation of agriculture between 1958 and 1960. Private land ownership was abolished in favour of state ownership. Productive land use was monopolised by state enterprises, organisations and co-operatives.

In the South, control of agricultural land by landlords was weakened considerably during the American war both through the land reform campaigns led by the National Liberation Front within the liberated zones and the flight of landlords to the cities. Reunification in 1975 was followed by a less successful attempt to collectivise agriculture in the South in 1978-9.

In the late 1970s and early 1980s, collective agriculture and the central planning system led to serious problems, including shortages, low productivity and inefficiency. Gradual decollectivisation started in 1981 with Contract 100, under which agricultural co-operatives began short-term contracting of agricultural land to individual households. Resolution 10, passed in 1988, confirmed the shift to household land tenure, by granting long term land use rights to households. Under the 1993 Land Law, land users were granted five rights to exchange, transfer, bequeath, lease and mortgage land use rights. Consistent certification of land use rights and registration of transactions was introduced with the issue of Land Use Right Certificates (LURCs).

Vietnam's land tenure system is characterised by a number of fundamental distinguishing factors which remain enshrined in the most recent land legislation, the 2003 Land Law:

- State ownership. "Land is the property of the whole people, and the State is the representative owner." (Article 5). The 2003 Land Law clearly restates this fundamental proposition.

- Land use right terms. Land use rights are granted for a fixed term on productive land. For agricultural land used for annual crops, aquaculture or salt production, the maximum term is 20 years. For agricultural land used for perennial crops and production forests granted to households, the maximum term is 50 years (Article 67). The law guarantees that land use right terms will be extended on expiry "if the land users are still in need of such land and have strictly complied with land legislation during the period of their occupancy and the use of such land is in accordance with the approved land use plan." (Article 67). Permanent land use rights are granted for residential land, protection forests and other categories (Article 66).

- Rights of land users. Land users can "exchange, transfer, lease, sub-lease, inherit, donate land use rights, mortgage, guarantee, make capital contribution in the form of land use rights." (Article 106). A detailed series of limitations on these rights is contained within the Land Law (Articles 109 - 121).

- Principles of land use. The 2003 Land Law restates that land must be used in accordance with land use plans and registered land purpose. Use must be economical, efficient, protective of the environment and respectful of the rights of neighbouring land users.

- Agricultural land reserves. Communes in Vietnam have traditionally retained a reserve of agricultural land for public use. Article 72 of the Land Law limits this reserve to $5 \%$ of total agricultural land area and stipulates allowable uses of this public reserve.

\section{RESEARCH METHODS}

The research project was designed, monitored and coordinated by an international mentor (Williamson) in collaboration with the ADB team and local researchers (see 
below) and was tested and refined in the field in June, 2004. The project was coordinated in Vietnam by a local researcher (Smith).

Three research teams conducted the field work in the three different regions of Vietnam: the Centre for Rural Progress (CRP) in the southern Mekong Delta, the Central Institute of Economic Management (CIEM) in Central Vietnam and Mekong Economics Ltd. In the Northern Red River delta. Field work was conducted in July and August 2004. An international land administration expert (Burns) analysed the results within the context of Vietnam's current land administration framework and drafted a joint set of policy recommendations based on these findings.

Each team selected two provinces in which to conduct the survey. Within each province, two districts were chosen and within each district, two communes (see Table 1). Three criteria were used to select provinces, districts and communes: high levels of LURC issue, relatively developed land markets and high incidence of poverty.

Table 1: Survey areas, population, poverty rates

\begin{tabular}{|c|c|c|c|c|c|c|}
\hline Region & Provinces & Districts & Popn. & $\begin{array}{r}\text { Poverty } \\
\text { rate } \\
\text { (MOLISA) }\end{array}$ & $\begin{array}{r}\text { Poverty } \\
\text { rate } \\
\text { (IPMG) }\end{array}$ & $\begin{array}{r}\text { Survey } \\
\text { communes }\end{array}$ \\
\hline \multirow[t]{4}{*}{ South } & \multirow[t]{2}{*}{ An Giang } & Thoai Son & 186,640 & $6 \%$ & $44 \%$ & $\begin{array}{l}\text { Vong Dong, } \\
\text { Thoai Giang }\end{array}$ \\
\hline & & Phu Tan & 253,803 & $4 \%$ & $38 \%$ & $\begin{array}{r}\text { Phu Lam, } \\
\text { Phu An }\end{array}$ \\
\hline & \multirow[t]{2}{*}{ Hau Giang } & Vi Thanh & 70,026 & $4 \%$ & $31 \%$ & $\begin{array}{r}\text { Ward } 7, \\
\text { Vi Tan }\end{array}$ \\
\hline & & Vi Thuy & 91,800 & $8 \%$ & $38 \%$ & $\begin{array}{r}\text { Vi Thang, } \\
\text { Vi Trung }\end{array}$ \\
\hline \multirow[t]{4}{*}{ Centre } & \multirow[t]{2}{*}{$\begin{array}{l}\text { Thua Thien } \\
\text { Hue }\end{array}$} & Quang Dien & 91,037 & $12 \%$ & $57 \%$ & $\begin{array}{l}\text { Quang Phuoc, } \\
\text { Quang Thanh }\end{array}$ \\
\hline & & Huong Thuy & 91,560 & $10 \%$ & $44 \%$ & $\begin{array}{r}\text { Thuy Duong, } \\
\text { Thuy Van }\end{array}$ \\
\hline & \multirow[t]{2}{*}{ Quang Nam } & Tien Phuoc & 72,081 & $24 \%$ & $55 \%$ & $\begin{array}{l}\text { Tien Lang, } \\
\text { Tien Canh }\end{array}$ \\
\hline & & Thang Binh & 84,615 & $17 \%$ & $41 \%$ & $\begin{array}{r}\text { Binh Tu, } \\
\text { Ha Lam }\end{array}$ \\
\hline \multirow[t]{4}{*}{ North } & \multirow[t]{2}{*}{ Bac Ninh } & Tu Son & 117,101 & $2 \%$ & $29 \%$ & $\begin{array}{l}\text { Chau Khe, } \\
\text { Dinh Bang }\end{array}$ \\
\hline & & Que Vo & 149,819 & $7 \%$ & $40 \%$ & $\begin{array}{c}\text { Nam Son, } \\
\text { Van Duong }\end{array}$ \\
\hline & \multirow[t]{2}{*}{ Hung Yen } & Khoai Chau & 180,606 & ND & $37 \%$ & $\begin{array}{r}\text { Binh Minh, } \\
\text { Da Trach }\end{array}$ \\
\hline & & Van Giang & 91,220 & ND & $35 \%$ & $\begin{array}{r}\text { Lien Nghia, } \\
\text { Me So }\end{array}$ \\
\hline
\end{tabular}

Notes

- MOLISA refers to the Ministry of Labour, Invalids and Social Affairs. MOLISA is responsible for defining the national poverty line. Since November 2000, MOLISA poverty criteria have been set at average monthly per capita income of 80,000 VND (highland areas), 100,000 VND (rural areas), 150,000 VND (urban areas). (approximately 15,000 VND = 1 USD)

- IPMG refers to the Interministerial Poverty Mapping Group. This group used the World Bank poverty definition to produce national poverty data compiled in a CD Rom (Poverty mapping and market access in Vietnam; Interministerial Poverty Mapping Task Force; $1^{\text {st }}$ October 2003). The data is based on the 1998 Household Living Standard Survey and a 33\% sample from the 1999 census. 
All of the 12 districts in which the research was conducted are primarily agricultural (see Table 2).

However, many are starting to experience the effects of a certain degree of urbanisation:

- Vi Thanh district has become the new provincial capital of Hau Giang province after its recent split from Can Tho province. There is pressure for switching from agricultural to residential land use as a result.

Table 2: Land area and types in survey districts

\begin{tabular}{|c|c|c|c|c|c|c|}
\hline $\begin{array}{l}\text { Province/ } \\
\text { District }\end{array}$ & $\begin{array}{l}\text { Total } \\
\text { land } \\
\text { area } \\
\left(\mathrm{km}^{2}\right)\end{array}$ & $\begin{array}{c}\% \\
\text { Agricultura } \\
I\end{array}$ & $\begin{array}{c}\% \\
\text { Residential }\end{array}$ & $\begin{array}{c}\% \\
\text { Forestry }\end{array}$ & $\begin{array}{c}\% \\
\text { Special } \\
\text { use }\end{array}$ & $\begin{array}{c}\% \\
\text { Unused } \\
I \\
\text { other } \\
\end{array}$ \\
\hline \multicolumn{7}{|l|}{ An Giang $^{2}$} \\
\hline Thoai Son & 459 & $83 \%$ & $5 \%$ & $0 \%$ & $10 \%$ & $2 \%$ \\
\hline Phu Tan & 307 & $80 \%$ & $5 \%$ & $0 \%$ & $8 \%$ & $7 \%$ \\
\hline \multicolumn{7}{|l|}{ Hau Giang ${ }^{3}$} \\
\hline Vi Thanh & 119 & $89 \%$ & $1 \%$ & $3 \%$ & $6 \%$ & $0 \%$ \\
\hline Vi Thuy & 230 & $91 \%$ & $1 \%$ & $1 \%$ & $5 \%$ & $1 \%$ \\
\hline \multicolumn{7}{|c|}{$\begin{array}{l}\text { Thua Thien Hue } \\
(2002)\end{array}$} \\
\hline Quang Dien & 163 & $43 \%$ & $3 \%$ & $9 \%$ & $13 \%$ & $32 \%$ \\
\hline Huong Thuy & 457 & $14 \%$ & $3 \%$ & $47 \%$ & $7 \%$ & $29 \%$ \\
\hline \multicolumn{7}{|l|}{$\begin{array}{l}\text { Quang Nam } \\
\text { (2002) }\end{array}$} \\
\hline Tien Phuoc & 453 & $40 \%$ & $5 \%$ & $1 \%$ & $26 \%$ & $28 \%$ \\
\hline Thang Binh & 385 & $42 \%$ & $10 \%$ & $9 \%$ & $14 \%$ & $25 \%$ \\
\hline \multicolumn{7}{|l|}{ Bac Ninh $^{4}$} \\
\hline Tu Son & 61 & $65 \%$ & $10 \%$ & $0 \%$ & $22 \%$ & $3 \%$ \\
\hline Que Vo & 171 & $62 \%$ & $5 \%$ & $2 \%$ & $18 \%$ & $14 \%$ \\
\hline \multicolumn{7}{|l|}{$\begin{array}{l}\text { Hung Yen } \\
(2000)\end{array}$} \\
\hline Khoai Chau & 131 & $67 \%$ & $8 \%$ & $0 \%$ & $19 \%$ & $6 \%$ \\
\hline Van Giang & 72 & $70 \%$ & $9 \%$ & $0 \%$ & $17 \%$ & $4 \%$ \\
\hline
\end{tabular}

- Huong Thuy district, situated on the edges of the city of Hue, is also experiencing urban encroachment.

- In the North, industrial zones and commercial-tourist zones are being established in all four of the districts surveyed. Industrialisation and urbanisation pressures are strongest in Dinh Bang and other communes of Tu Son district.

It was agreed that the three teams would investigate:

- Four types of land market process: the initial allocation of LURCs, transfer (salepurchase) of land use rights, rental and mortgage.

- Transactions when conducted formally, according to the full legal requirements, and informally, without legal registration.

- Descriptions of formal transactions from the perspective of local land administration officials (commune cadastral officers and District DONRE), as well as from the perspective of households actually involved in the transactions.

- Detailed procedural steps, parties involved, costs incurred and the time required to complete transactions, to be documented in flow charts.

\footnotetext{
${ }^{2}$ Thoai Son: Population figures, MOLISA poverty rates and land area and types -2002 . Phu Tan: poverty rate - 2004; Population figures - ; land area and types -

${ }^{3}$ Hau Giang: Population figures - ; MOLISA poverty rates - land area and types -

${ }^{4}$ Bac Ninh: Population figures - 2000; MOLISA poverty rates - 2003; land area and types -2003 .
} 
- Particular regulations, local variations, difficulties and issues relevant to these transactions, to be noted next to the flow charts.

- At least six individual case studies of households involved in the three targeted types of land transaction, both formal and informal.

It was agreed that representatives of the following district level government departments would be interviewed: District People's Committee, Department of Natural Resources and the Environment (DONRE) or local equivalent, Tax Department and Vietnam Bank of Agriculture and Rural Development (VBARD) branch. In some cases, research teams also held meetings with equivalent departments at the provincial level.

The research teams were asked to interview at least 80 households in each region (10 per commune). The main selection criterion was that the household had been recently involved in one of the targeted types of land transaction, either formally or informally. Teams were encouraged to include as many poor households as possible within the interview sample. It should be emphasised that, as the field work was not aimed at measuring land market development or the extent of informality, the interview sample was not designed to be representative of the general population in the localities selected. Rather, the sample was specifically designed to include as many land market participants as possible who could shed light on the processes involved.

In practice, household interviews covered a total of 348 transactions (see Table 3), of which 249 were formal land transactions and 99 were informal transactions. Sale purchases were the most frequently discussed transactions (158 cases), followed by mortgage (122 cases) and rental (68 cases). The Central study team reported that $11 \%$ of their 91 interviewees were poor households. Four of the 76 interviewees in the Northern study were categorised as poor under criteria established by the Ministry of Labour, Invalids and Social Affairs (MOLISA) ${ }^{5}$. None of the interviewees in the Southern study were officially poor by MOLISA criteria, though the team judged 20 out of 76 interviewees to be poor by subjective assessment.

Table 3: Number of transactions examined in household interviews

\begin{tabular}{|c|c|c|c|c|c|c|c|}
\hline $\begin{array}{l}\text { Province } \\
\text { District }\end{array}$ & $\begin{array}{r}\begin{array}{r}\text { Formal } \\
\text { sale }\end{array} \\
\end{array}$ & $\begin{array}{r}\text { Formal } \\
\text { rental }\end{array}$ & $\begin{array}{r}\text { Formal } \\
\text { mortgage }\end{array}$ & $\begin{array}{r}\text { Informal } \\
\text { sale }\end{array}$ & $\begin{array}{r}\text { Informal } \\
\text { Rental }\end{array}$ & $\begin{array}{r}\text { Informal } \\
\text { mortgage }\end{array}$ & Total \\
\hline \multicolumn{8}{|l|}{ An Giang } \\
\hline Thoai Son & 13 & 0 & 14 & 3 & 5 & 1 & 36 \\
\hline Phu Tan & 8 & 0 & 10 & 2 & 3 & 3 & 26 \\
\hline \multicolumn{8}{|l|}{ Hau Giang } \\
\hline Vi Thanh & 7 & 0 & 13 & 2 & 1 & 3 & 26 \\
\hline Vi Thuy & 5 & 0 & 12 & 4 & 1 & 2 & 24 \\
\hline \multicolumn{8}{|l|}{ Thua Thien } \\
\hline Hue & 4 & 1 & 18 & 0 & 3 & 1 & 27 \\
\hline $\begin{array}{l}\text { Quang Dien } \\
\text { Huong Thuy }\end{array}$ & 20 & 2 & 4 & 0 & 3 & 0 & 29 \\
\hline \multicolumn{8}{|l|}{ Quang Nam } \\
\hline Tien Phuoc & 6 & 0 & 6 & 8 & 2 & 0 & 22 \\
\hline Thang Binh & 10 & 0 & 6 & 7 & 2 & 0 & 25 \\
\hline \multicolumn{8}{|l|}{ Bac Ninh } \\
\hline Tu Son & 12 & 1 & 4 & 3 & 7 & 0 & 27 \\
\hline Que Vo & 19 & 0 & 10 & 1 & 6 & 0 & 36 \\
\hline \multicolumn{8}{|l|}{ Hung Yen } \\
\hline Khoai Chau & 10 & 8 & 7 & 2 & 10 & 0 & 37 \\
\hline Van Giang & 10 & 1 & 8 & 2 & 12 & 0 & 33 \\
\hline Total & 124 & 13 & 112 & 34 & 55 & 10 & 348 \\
\hline
\end{tabular}

\footnotetext{
${ }^{5}$ Since November 2000, MOLISA poverty criteria have been set at average monthly per capita income of 80,000 VND (highland areas), 100,000 VND (rural areas), 150,000 VND (urban areas).
} 


\section{RESULTS}

The research results summarised below are outlined in detail in the three regional studies, the land administration report and the project summary report, all of which are available on the Making Markets Work Better for the Poor website (http://www.markets4poor.org).

\section{Extent of informality}

The research showed that significant progress has been made in the granting of formal land use titles to households. LURCs for agricultural land have been granted to over $70 \%$ of households in 10 of the 12 districts surveyed (see Table 4 ).

\begin{tabular}{llrr}
\multicolumn{5}{c}{ Table 4: Extent of LURC issue in survey districts } \\
\hline Province & District & $\begin{array}{r}\text { \% agricultural land } \\
\text { with LURC }\end{array}$ & $\begin{array}{r}\text { \% residential land } \\
\text { with LURC }\end{array}$ \\
& Thoai Son & $99 \%$ & $40 \%$ \\
\hline An Giang & Phu Tan & $99 \%$ & $29 \%$ \\
\hline Hau Giang & Vi Thanh & $70 \%$ & ND \\
& Vi Thuy & $96 \%$ & ND \\
\hline Thua Thien Hue & Quang Dien & $96 \%$ & $65 \%$ \\
& Huong Thuy & $54 \%$ & $55 \%$ \\
\hline Quang Nam & Tien Phuoc & $79 \%$ & $20 \%$ \\
& Thang Binh & $73 \%$ & $22 \%$ \\
\hline Bac Ninh & Tu Son & $97 \%$ & $84 \%$ \\
& Que Vo & $>70 \%$ & ND \\
\hline Hung Yen & Khoai Chau & $75 \%$ & $57 \%$ \\
& Van Giang & $43 \%$ & $74 \%$ \\
\hline
\end{tabular}

$\mathrm{ND}=$ No determination

There are two main types of LURC issue: mass issue on a village or commune wide basis and individual issue, often requested by households prior to transferring or mortgaging land. The procedures for LURC issue are clearly set out in a Circular of the General Department of Land Administration ${ }^{6}$. In all three studies, it was reported that LURC issue took from 1 to 2 months, excluding time for land survey which, in the case of mass issue, could take several months. Figure 1 contains an example flowchart for LURC issue documented in the Central region study. Administrative costs (purchase of application forms, cadastral fees etc.) were low ${ }^{7}$, with charges of 10,000 VND to 50,000 VND (approximately $0.64-3.18$ USD), excluding surveying costs, per LURC reported. This situation contrasts sharply with some of the examples quoted by De Soto of time and cost associated with formalisation of land tenure in the Philippines and elsewhere.

As land values increase, households increasingly seek to register land use right transfers formally. Procedures are relatively quick and simple ${ }^{8}$. Most land use transfers

\footnotetext{
${ }^{6}$ General Department of Land Administration Circular 1990/2001/TT-TCDC (30 ${ }^{\text {th }}$ November 2001) guiding land registration, cadastral records and issue of land use right certificates.

${ }^{7}$ According to Ministry of Finance Circular 93/2002/TT-BTC (21 $1^{\text {st }}$ October 2002), fees for cadastral services outside of the main cities are set as follows: issue of LURC - 10,000 VND (approximately 64 US cents) per certificate; duplication of map from cadastral records $-10,000 \mathrm{VND}$, certification of legality of land documents - 10,000 VND

${ }^{8}$ Procedures for registration of land use right transfers are set out in Government Decree 17/1999/NDCP $\left(29^{\text {th }}\right.$ March 1999) on 'procedures for exchange, transfer, leasing, sub-leasing and bequeathing land use rights and using land use rights as collateral or capital contribution' and Government Decree $79 / 2001 /$ ND-CP $\left(1^{\text {st }}\right.$ November 2001$)$ amending some articles of the above decree.
} 


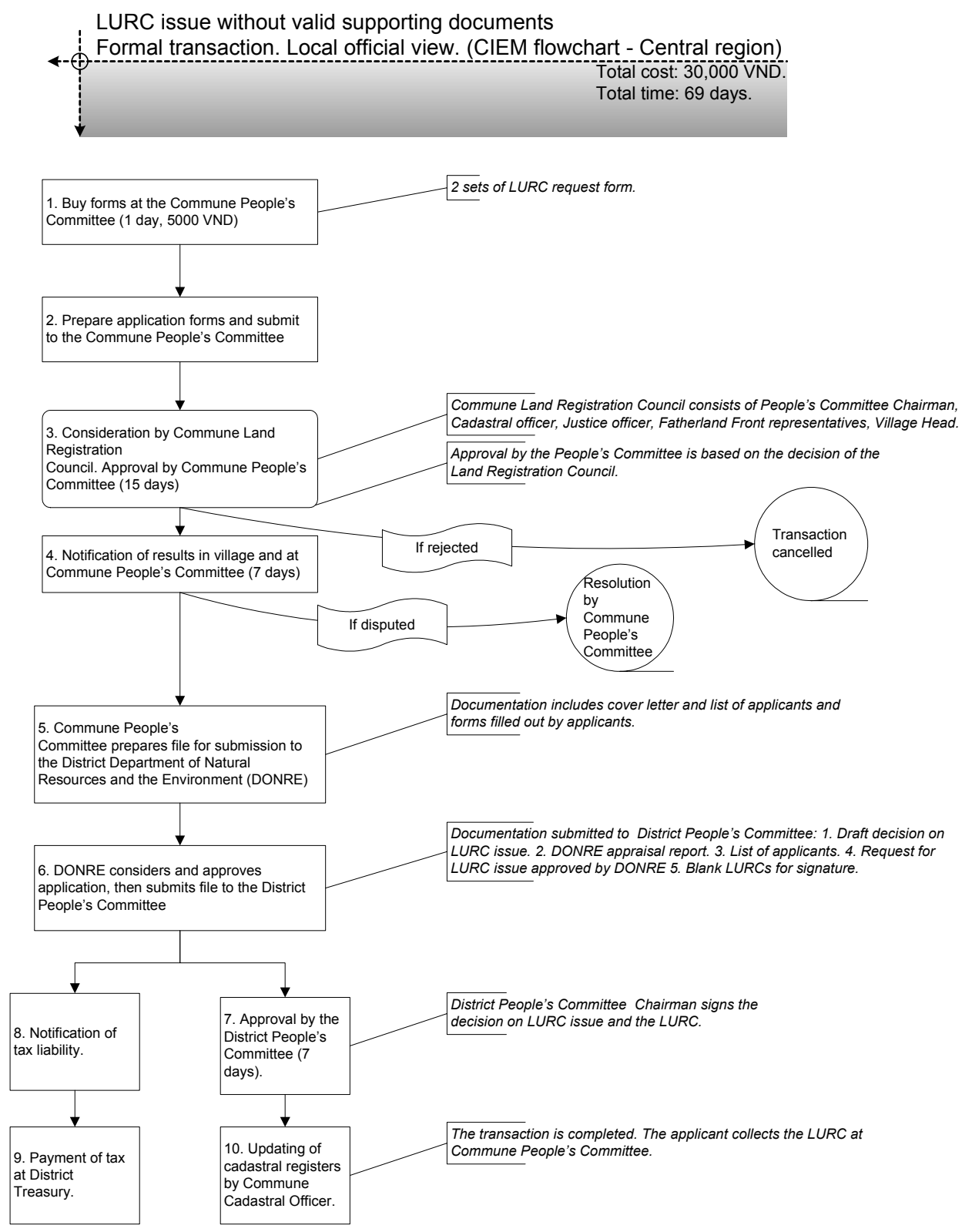

Fig. 1 Example of flow chart for LURC issue without valid supporting documents (Formal transaction, local official view) in the Central Region study by CIEM.

are registered within 1-2 months. Administrative charges were reported to vary from $15,000 \mathrm{VND}$ to $50,000 \mathrm{VND}$ (approximately $1-3.18 \mathrm{USD}$ ) per transaction, plus surveying costs in certain cases. Since 2000, official transfer taxes and fees have been reduced to what are considered low levels by international standards. Land use transfer tax of $2 \%$ is charged on agricultural land and $4 \%$ on residential land, with a $1 \%$ stamp 
IMPACT OF LAND MARKET PROCESSES ON THE POOR IN RURAL VIETNAM

duty ${ }^{9}$. Table 5 contains an example of a formal land transfer transaction documented in An Giang province.

Table 5: Sale of land use right. Formal transaction. Official view (CRP flowchart)

\begin{tabular}{|c|c|c|c|c|}
\hline Step & Activities & $\begin{array}{l}\text { Parties } \\
\text { involved }\end{array}$ & $\begin{array}{l}\text { Time } \\
\text { (days) }\end{array}$ & $\begin{array}{l}\text { Cost } \\
\text { (VND) }\end{array}$ \\
\hline 1 & $\begin{array}{l}\text { Buyer and Seller, after agreement on land purchase, meet } \\
\text { Commune cadastral officer (CCO) to buy the application form and } \\
\text { request assistance. }\end{array}$ & $\begin{array}{l}\text { Buyer, seller, } \\
\text { CCO,CPC }\end{array}$ & \multirow[t]{3}{*}{1} & 15,000 \\
\hline 2 & $\begin{array}{l}\text { Both parties fill out the forms with assistance from CCO. All } \\
\text { family members of the seller aged over } 18 \text { must sign the form or } \\
\text { an authorized letter indicating agreement to sell that land. }\end{array}$ & $\mathrm{CCO}$ & & \\
\hline 3 & $\begin{array}{l}\text { Application file is handed to CCO (the contract, authorisation by } \\
\text { family members, Certificate of Land Quota, LURC, as well as the } \\
\text { resident register book and identity card for both parties. }\end{array}$ & $\mathrm{CCO}$ & & \\
\hline 4 & $\begin{array}{l}\text { CCO checks again and verifies the accuracy of the land in terms of } \\
\text { location and status of any disputes. The form is then submitted to } \\
\text { CPC for authorisation signature and stamp. }\end{array}$ & $\mathrm{CCO}, \mathrm{CPC}$ & \multirow[t]{2}{*}{1} & \\
\hline 5 & $\begin{array}{l}\text { If land is sold as a full parcel then no measurement is required. In } \\
\text { case of segmentation then the CCO must go to the plot to measure } \\
\text { and to draw the sketch map of the land. }\end{array}$ & $\mathrm{CCO}$ & & \\
\hline 6 & Buyer/seller submits full app to District's Receiving Office (DRO) & DRO & 1 & \\
\hline 7 & $\begin{array}{l}\text { DRO receives the application file, prepares a receipt for the } \\
\text { applicants and the file is then transferred to the District Cadastral } \\
\text { Office (DCO). }\end{array}$ & $\begin{array}{l}\text { DRO \& } \\
\text { DCO }\end{array}$ & \multirow[t]{4}{*}{4} & \\
\hline 8. & $\begin{array}{l}\text { DCO verifies the applicant's file on the computer to check full } \\
\text { name, area and position of plot. If the information is valid, then } \\
\text { continue to step 9. If not, the application is returned to DRO with } \\
\text { feedback to the applicant within } 4 \text { working days. }\end{array}$ & $\mathrm{DCO}$ & & \\
\hline 9 & $\begin{array}{l}\text { DCO prepares a letter requesting District People's Committee } \\
\text { (DPC) to approve the applications. The new LURC is then } \\
\text { prepared with signature of DPC vice chairman and stamped. }\end{array}$ & $\mathrm{DCO}, \mathrm{DPC}$ & & \\
\hline 10 & DCO returns the applicant file through DRO payment of tax. & DRO & & \\
\hline 11 & DRO returns documents to buyer/seller. & $\overline{\mathrm{DRO}}$ & \multirow{7}{*}{1} & \\
\hline 12 & $\begin{array}{l}\text { Land buyer/seller brings the approved application to District Tax } \\
\text { Division (DTD) to pay tax liabilities. }\end{array}$ & DTD & & \\
\hline 13 & DTD calculates taxes for land use right transfer. & DTD & & \\
\hline 14 & $\begin{array}{l}\text { DTD asks Commune based tax team (CTT) to verify the accuracy } \\
\text { of the profile if necessary. }\end{array}$ & DTD, CTT & & \\
\hline 15 & $\begin{array}{l}\text { Land buyer/seller fills in Tax Payment form. Tax liabilities are } \\
\text { prepared by tax officers. }\end{array}$ & DTD & & \\
\hline 16 & $\begin{array}{l}\text { Tax is paid directly to District Treasury. 'Tax-paid' receipt is } \\
\text { obtained. }\end{array}$ & DTD & & $\begin{array}{l}\text { Transfer } \\
\text { tax } 4 \% \text {; } \\
\text { SD } 1 \% \text {. }\end{array}$ \\
\hline 17 & $\begin{array}{l}\text { Receipt for tax payment is then handed back to DRO. } 20 \text { working } \\
\text { days is requested to complete procedures. }\end{array}$ & DRO & & \\
\hline 18 & $\begin{array}{l}\text { DRO, after receiving back the file from the applicant with } \\
\text { evidence of tax payment, then hands it on to DCO for completion } \\
\text { of procedures. }\end{array}$ & $\mathrm{DCO}$ & \multirow[t]{5}{*}{20} & \\
\hline 19 & DCO prepares a proposal to request DPC to approve the transfer. & $\mathrm{DCO}$ & & \\
\hline 20 & Vice Chairman of DPC signs the LURC. & DPC & & \\
\hline 21 & $\begin{array}{l}\text { District cadastral office updates information in cadastral books and } \\
\text { computer programs }\end{array}$ & $\mathrm{DCO}$ & & \\
\hline 22 & $\begin{array}{l}\text { The new LURC is issued and the Cadastral office returns it to the } \\
\text { Receiving Office. }\end{array}$ & DCO, DRO & & \\
\hline 23 & $\begin{array}{l}\text { Buyer/seller after } 20 \text { working days comes to collect the new } \\
\text { LURC from Receiving Office desk }\end{array}$ & DRO & 1 & 10,000 \\
\hline Total & 23 steps & & 29 & 25,000 \\
\hline
\end{tabular}

\footnotetext{
${ }^{9}$ Land use transfer tax rates stipulated in Government Decree $19 / 2000 /$ ND-CP $\left(8^{\text {th }}\right.$ June 2000$)$. Regulations on stamp duty outlined in Decree 176/1999/ND-CP (21 ${ }^{\text {st }}$ December 1999).
} 
The An Giang survey showed that the formal land market is relatively active: around $5 \%$ of agricultural land plots are transferred formally each year (see Table 6).

Table 6: No. of registered LURC transfers as \% of total LURCs issued

\begin{tabular}{llccc} 
Land type & Period & \multicolumn{2}{c}{ An Giang } & Hau Giang \\
\cline { 3 - 5 } & & Thoai Son & Phu Tan & Vi Thuy \\
\hline Agricultural & 2002 & $5.4 \%$ & $5.3 \%$ & $8.0 \%$ \\
& 2003 & $6.3 \%$ & $6.2 \%$ & $8.8 \%$ \\
& January - June 2004 & $2.9 \%$ & $3.1 \%$ & $2.6 \%$ \\
\hline Residential & 2002 & $3.7 \%$ & $0.5 \%$ & \\
& 2003 & $3.4 \%$ & $0.9 \%$ & \\
& January - June 2004 & $1.5 \%$ & $0.6 \%$ & \\
\hline
\end{tabular}

Anecdotal evidence from the Northern and Central regions suggests that the transfer market is active mainly for residential land use rights, with very few transactions in agricultural land. Indeed, the district tax office in Khoai Chau district, Hung Yen province, claims not to have collected any land use right transfer tax on agricultural land between 2002 and June 2004.

Mortgaging of LURCs is also an increasingly simple and common procedure at the Vietnam Bank of Agriculture and Rural Development (VBARD). Figures from An Giang indicate that $15-33 \%$ of agricultural land use holders use their LURCs as collateral for loans from VBARD each year (see Table 7).

\begin{tabular}{|c|c|c|c|c|}
\hline \multirow[t]{2}{*}{ Land type } & \multirow{2}{*}{ Period } & \multicolumn{2}{|c|}{ An Giang } & Hau Giang \\
\hline & & Thoai Son & Phu Tan & Vi Thuy \\
\hline \multirow[t]{3}{*}{ Agricultural } & 2002 & $17.5 \%$ & $15.3 \%$ & $29.9 \%$ \\
\hline & 2003 & $17.3 \%$ & $22.2 \%$ & $32.3 \%$ \\
\hline & January - June 2004 & $11.4 \%$ & $8.6 \%$ & $23.7 \%$ \\
\hline \multirow[t]{3}{*}{ Residential } & 2002 & $13.0 \%$ & $4.0 \%$ & $\overline{\mathrm{ND}}$ \\
\hline & 2003 & $12.6 \%$ & $7.2 \%$ & ND \\
\hline & January - June 2004 & $3.9 \%$ & $1.1 \%$ & ND \\
\hline
\end{tabular}

Mortgage procedures take from 5 days to 2 weeks to complete and the administrative costs of processing are low (2-30,000 VND per transaction i.e. approximately $0.13-$ 1.91 USD). Figure 2 contains an example of a formal mortgage transaction with the Vietnam Bank of Agriculture and Rural Development documented in the Northern region study.

Informality continues to thrive, however, in various sections of the land market:

- The issue of LURCs is proceeding more slowly for residential land than for agricultural land. In only 2 of the 12 districts surveyed have more than $70 \%$ of households received LURCs for residential land (See Table 4).

- The land rental market remains almost exclusively within the informal sector. Neither landholders nor cadastral authorities seem interested in registering rental transactions.

- While it is impossible to quantify the scale of informal sales, transfers are sometimes left unregistered, or are registered semi-formally at commune level only. This phenomenon is most common when transacting parties know each other well or are related, when the plot does not have an LURC and when it is intended that land use purpose will be changed. 


\section{IMPACT OF LAND MARKET PROCESSES ON THE POOR IN RURAL VIETNAM}

- Despite the growth in bank mortgages, an informal 'mortgage' transaction known as 'co dat' thrives in the Mekong Delta.

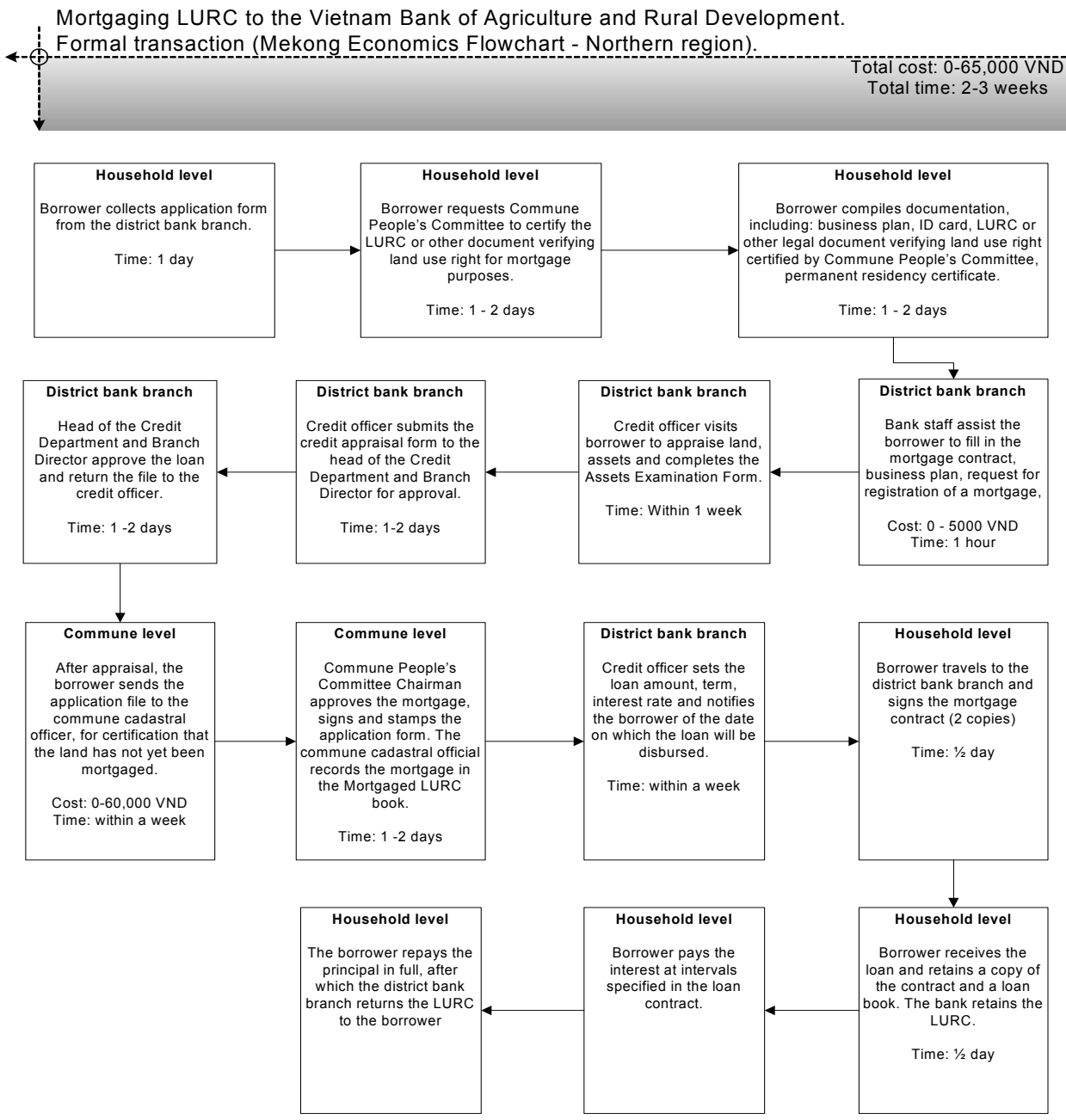

Fig.2. Flowchart of mortgaging LURC to Vietnam Bank of Agriculture and Rural Development (Formal transaction) Northern Region by Mekong Economics

Informal agricultural land rental. (CIEM case study)]

Mr. P. and his family live in Quang Nam. In 2002, he decided to lease out one of his rice land parcels. The rent was 420,000 VND/year (approximately 27 USD) for a parcel of $1500 \mathrm{~m}^{2}$. The parties agreed and signed a hand-written contract. The lease term was left blank. If he wants to take the land back, Mr. P. will just inform the other party one crop season in advance. Mr. P. has been paid the rent every year since then. The irrigation fees are paid by the leasing-in party while the leasing-out party takes care of other fees and charges. There have been no disputes. Mr. P. said he did not know that he had to register the lease with the commune. He also said he was not afraid that the land would not be returned because both parties knew each other well. 
'Co dat'- informal mortgages in the Meking Delta. (CRP case study)

The 'co dat' transaction involves households swapping the use of land plots for cash loans, usually equivalent to around one third of the sale value of the plot, for a fixed period, usually 3 years. No loan interest or land rental is paid: the lender enjoys income from the use of the land.

Mr. B., born in 1953, lives in Vi Thuy District, Hau Giang Province. The family owns 3 parcels of land. In order to scale up production, Mr. B. informally 'mortgaged' three additional parcels of paddy land. The first parcel was 4,290 $\mathrm{m}^{2}$. In exchange for the use of this parcel for 3 years, he lent out 18 million VND. For the second parcel of $7,150 \mathrm{~m}^{2}$ and the third parcel of 7,800 $\mathrm{m}^{2}$, he lent out 25 million VND to each owner in exchange for the use for 3 years. The current market prices of these parcels were 58 million VND, 96 million VND and 105 million VND respectively. The process of mortgaging was simple: the two parties met to determine the terms of trade and duration. They made and signed hand written contracts with two witnesses, who have adjacent land parcels. Then they exchanged land for money. The red books did not change hands. The transaction was not reported to the commune authorities

\section{Reasons for informality}

The causes of continued informal land tenure and transactions can be traced both to land users themselves and the formal system of land administration.

i) Lack of awareness or information on the part of land users. In a number of cases in the Southern study, failure to register transactions resulted from land users being unaware of the dangers of informality. One household purchased a plot even though the seller refused to transfer formal title. Other households bought land already mortgaged to the bank and therefore were unable to register the transfers.

ii) Problems with the issue of LURCs. Particular problems with LURC issue include: high land use levies charged for the issue of LURCs on residential land and for the conversion of garden to residential land ${ }^{10}$ (see Table 8). For example, levies of $100 \%$ of the plot value are charged on residential land occupied since 1993. In one An Giang commune, 483 out of 908 residential LURCs had been left uncollected at the commune office because land holders were reluctant to pay the land use levies.

More detailed information from An Giang province gives some idea of the level of payments. Provincial land area ceilings effective in An Giang are $300 \mathrm{~m}^{2}$ per household for urban areas and $600 \mathrm{~m}^{2}$ per household for rural areas. According to provincial price frameworks, residential land in Thoai Son district is valued at 6100 VND per $\mathrm{m}^{2}$. A household seeking issue of an LURC on a $600 \mathrm{~m}^{2}$ residential plot occupied since after 1993 would therefore have to pay 3,660,000 VND (approximately 230 USD) in land use levy to receive the certificate.

Other issues related to the issue of LURCs include:

- Relatively high plot surveying costs borne by land users seeking individual LURC issue in some areas (300,000 VND, or approximately 19 USD, per 1000 $\mathrm{m}^{2}$ quoted in An Giang).

- In some cases, the skills of cadastral officials have been a significant constraint to land titling.

\footnotetext{
${ }^{10}$ The rates charged for various categories of plot are set out in Decree 38/2000/ND-CP (23 ${ }^{\text {rd }}$ August 2000).
} 
- The legal ceiling on maximum agricultural land holdings of 3 ha per household also has some impact in Southern Vietnam where average land holdings are much higher than in the North and Centre. Households with larger landholdings have to avoid this restriction by means of transferring legal ownership to other relatives.

iii) Problems with registering LURC transfers. Local informal 'fees' were reported as a particular obstacle to formal registration in North and Central Vietnam. The Northern study comments "Of the households interviewed, those who agreed to informal fees paid an average of 50,000 to 500,000 VND (approximately $3.18-$ 31.85 USD) on top of the tax for the land transaction. One household has waited over a year for the commune to measure their land because they did not pay the informal fees of 300,000 VND required by a commune cadastral official. There were also 2 cases that the procedure lasted for 6 months though the buyer had to pay 50,000 VND to the commune cadastral officer for his help." In the central study, a case was found of systematic informal fees levied by the commune authorities being semi-'formalised' as a compulsory contribution to a commune infrastructure fund.

Compulsory informal fees - Commune 'infrastructure' fund. (CIEM case study) In early 2004, Mr. A decided to sell half a parcel of land to his brother. They agreed that Mr. A would take care of all the required procedures. Mr. A went to the commune and bought a set of forms for the transfer. The commune levies a fee on all land transactions for the commune 'infrastructure fund'. This fee is $5,000 \mathrm{VND} / \mathrm{m}^{2}$ if the land is transferred between relatives as a gift, $2 \%$ of the transaction value if the land is sold and $10 \%$ of the transaction value if it is the land allocated by the commune.

To have the transfer contract approved by the commune, this fee must be paid. The commune also keeps a close eye on the construction of residential buildings. Building is forbidden on any unofficially transferred parcel.

After submission of the documents to the commune, the commune cadastral officer came to mark the new boundary and survey the divided parcel. Mr. A appealed to the Commune Land Valuation Council to treat the transaction as a family gift instead of a sale. The commune fee was then VND 5000/ $\mathrm{m}^{2} \times 250 \mathrm{~m}^{2}$ $=V N D 1.25$ million. Mr. A said he could not afford both the fee and the 5\% tax, so he would just pay 1.25 million VND to the commune to get commune approval for the contract. As for formalities at the district, he would do it when he had enough money.

Other obstacles to formal registration of land transfers include:

- Local officials sometimes requiring extra documentation to process transfers (e.g. signatures of neighbours, copies of buyer's residency registration etc.).

- Costly and time consuming procedures for transfer of land on which an LURC has yet to be issued as allocation and transfer processes have to be completed simultaneously.

- Negotiated and untransparent processes of land valuation for transfer tax purposes resulting form the wide disparity between provincial land price frameworks and actual market prices.

- Active intervention by local governments in some provinces like Hau Giang to prevent transfers of small land plots in an attempt to prevent plot fragmentation. 
iv) Problems with mortgaging LURCs. Some cases of unofficial fees demanded by bank officials were discovered in the Northern districts. "Two households paid unofficial fees $(100,000 \mathrm{VND}$ and 200,000 VND respectively) in order to get loans. These individuals were asking for loan sizes over 10 million VND. To quicken the borrowing process, two other households paid 100,000 VND to bank staff. One household received the loan within 1 day paying an unofficial fee of 50,000 VND." Internal bank regulations - including limits on lending up to $50 \%$ of the value of agricultural land use rights used as collateral - were cited as constraints in the Southern study.

\section{EFFECTS OF INFORMALITY}

De Soto argues that formal land title would have a range of 'property effects' which increase the value of land to the landholder and to society as a whole. The case studies selected by the three research teams do show some of the adverse effects that continued informality can have in the rural land market:

- Households without formal tenure were unable to gain the full value of their assets when selling land use rights on the market. Those mortgaging land informally in the Mekong Delta are also able only to leverage around $25-33 \%$ of the value of their land assets in loans, compared with 50\% at VBARD. (De Soto's Property Effect 1 'Fixing the economic potential of assets')

Informal tenure is less valuable. (CIEM case study)

Mr. E. is a carpenter living in the outer part of $\mathrm{Ha}$ Lam district town, Thang Binh district. He has built a house and carpentry workshop on the plot. Mr. E. bought the $273 \mathrm{~m}^{2}$ plot from Mr. P., a neighbour, in 2000. The plot, which used to be part of Mr. P's garden, does not have an LURC.

Now Mr. E. wants to sell the rights to use this land as he has found another parcel which is larger and farther from residential areas. According to current legislation, to make the transfer official, Mr. E. must change the land use purpose from garden to residential land (with tax payment of 100\% of the land value) and legalise the transfer between Mr. P. and himself (another payment of $4 \%$ of the value of the land)

Mr. E. cannot afford such payments as he needs funds to invest in his business. Therefore he decided to sell the plot informally at a lower price. The plot would have sold for 40 million VND if it had a LURC. But without the LURC, the highest price offered was 27 million. What's more, very few people want to buy it because of its illegal status

- Without LURCs, some households also found difficulties in using their land assets to gain access to loans (De Soto's Property Effect 4 - 'Making assets fungible').

- Ownership disputes, even between family members, were commonly reported to result when transactions are not registered. In such cases, land title is not clearly defined by legal title or recognised by the state. (De Soto's Property Effect $6-$ 'Protecting Transactions')

Informal land markets result in ownership disputes. (Mekong Economics case study)

Mr. B. 's plot was allocated to him with an LURC in 1996. At the end of that year, he sold the plot to Mr. Q. for 13 million VND. The two sides signed an 
informal written agreement. Mr. Q. paid for the land and received the Red Book. However, the registered land user remained unchanged as the transaction was not reported to the commune authorities.

At the end of 2003, Mr. B. petitioned the Commune People's Committee about a missing Red Book. At the same time, Mr. Q. handed in an Application for Registration of Land Use Rights Transfer to the commune. When the commune cadastral officer started investigating, Mr. B. denied selling the land.

The dispute has reached beyond the commune and district level as Mr. Q. holds the Red Book for the land in dispute. The two sides have now brought this lawsuit to the court at the province. One year has passed and no settlement has been reached so far.

Difficulty in accessing finance with informal land tenure.

(Mekong Economics case study)

Mr. N., head of a poor household, needed money to fund his business but, like many other poor households, he owned untitled land. Despite this, he decided to apply for a loan from the bank. The bank, however, refused.

Mr. N. considered applying for an LURC but procedures were too complicated and he could not afford the cost. He would have to have papers verifying his land use right confirmed by the Commune People's Committee. He would also have to pay a land use levy for changing land use purpose from garden to residential land $100 \%$ of the land value set by the Commune People's Committee). On top of that, he would also have to pay a 35,000 VND registration fee. It would take more than 1 month for the LURC to be issued.

Hopeless, he had no valuable assets, no one to borrow money from, and no one to apply for the loan for him. He had no other option but to sell half of his land through an informal transaction to fund his business.

Other evidence shows, however, that the 'transforming' effects of formal land title on the lives of poor people can be exaggerated. The study highlighted how formal land title systems, if implemented inaccurately and inefficiently, can themselves have detrimental impacts on the poor - particularly through inaccurate measurement of plot size.

The dangers of inaccurate plot measurement. (CIEM case study)

In Thua Thien Hue province, the land survey was not done correctly. LURCs were issued based on self-declaration by land users. Documents other than the land use certificate (allocation decision, inheritance deed, land inventory record etc.) also did not include the correct data. This leads to differences between what is recorded in LURC and the land that is really used. In many cases, when the land is accurately surveyed, the real area is much larger than what is recorded in the LURC.

This problem has been solved by way of auctioning the land use rights for the "surplus" area. In fact, a number of users have lost their land this way while it is not really their fault. In case the surplus area is not large, the user has to pay a certain sum of money (nobody would say how much) for a "new" LURC.

Evidence also suggests that, despite the lack of any formal registration, thriving land rental markets have developed in rural areas. Formal land title was found in some districts to not be an essential condition for mortgaging land with the banks. The cost 
and inefficiencies of legal processes for foreclosure on collateral also raise questions about the decisive role of legal land title in the mortgage market.

\section{CONCLUSIONS AND RECOMMENDATIONS}

Despite the issues and problems described above, it is clear that an efficient and accurate formal land administration system can bring significant benefits to poor people through improved security of tenure, reduced boundary and ownership disputes, opportunities to access finance and higher land values. Making formal procedures simpler, reducing transaction costs and increasing the access of poor people to formal land registration is believed likely to contribute more to poverty reduction than measures seeking to protect poor households from market forces in land. The recommendations that follow are therefore aimed at increasing the efficiency, speed and inclusiveness of land market mechanisms in the context of implementing Vietnam's new Land Law.

In addition to the policy recommendations, the research shows that the methodology of documenting transaction processes as proposed by Hernando de Soto, and subsequently expanded and refined, for both formal and informal processes, was a useful tool for examining the extent of informality, its causes and its impact on the poor. It is planned that this methodology will be adapted for use in a study of urban land issues and poverty in Vietnam in a future research project.

The key recommendations for improving the operation of the land market as a result of this research are as follows:

Improved infrastructure. Support is needed for the establishment of new provincial and district land registries which will provide the land registration services outlined in the new Land Law.

Increased capacity. The shift from a state management to a service provision culture within the land registries will require significant investment in training at all levels.

Increased public awareness. Public awareness campaigns are necessary to publicise the obligations and rights of land users, particularly with regard to cost and time promises for the delivery of services.

Clear commitment on time and cost. To ensure compliance with commitments on the cost and time of services outlined in the new Land Law, action will be needed to ensure efficient complaint channels, oversight of land administration services, perhaps by civil society organisations, and adequate funding of land administration offices.

Affordable fees and taxes. With the imminent issue of new decrees on land taxes and levies, it is important to ensure that fees are low enough to bring people into the formal system and to keep them there. International best practice suggests that the cost of initial allocation of title should be underwritten by the state. The issue of land use levies on residential land should therefore be closely monitored. Transfer taxes at present are currently low enough - and should not constitute a disincentive for formal registration.

Implementation of positive steps on women's land rights and fee waivers. The new Land Law includes measures to safeguard women's rights to matrimonial property and to reduce or waive land fees and levies for registered poor households. Priority should be given to implementation of these measures.

Review scope of state land administration role. In order to reduce administrative workload and increase efficiency, a number of streamlining measures should be considered. After the introduction of a land title system on the Torrens model at district level land registries, it may not be necessary for communes to keep duplicate records of cadastral information. The need to register rental transactions could also be 
reviewed. Annual and five yearly land inventories may not be necessary when new land registries update transactions within set time limits.

\section{ACKNOWLEDGEMENTS}

This research was conducted under the Making Markets Work Better for the Poor (MMWBP) project - see http://www.markets4poor.org/index.php for further information This is an Asian Development Bank (ADB) research project co-funded by the UK Department for International Development (DFID) and the Asian Development Bank Institute. Specific additional funding for this study was received from AusAID. The project was supported by Vietnam's Ministry of Natural Resources and the Environment (MONRE). Particular acknowledgements are due to Prof. Dang Hung Vo, Vice Minister at MONRE, who facilitated the project and contributed ideas. The authors would also like to thank Alan Johnson and Le Cong Luyen Viet of ADB, members of the three research teams as well as all government officials and households who took part in the interviews. The views and opinions expressed are those of the authors and do not necessarily reflect the views of the Government of Vietnam, the Asian Development Bank or the institutions for which the authors work.

\section{References}

1. De Soto H., 2000. The Mystery of Capital: Why Capitalism Triumphs in the West and Fails Everywhere Else. London, Black Swan.

2. Fernandes, Edesio, 2002. The influence of de Soto's 'The Mystery of Capital'. Land Lines. V.14.No.1

3. Gilbert, A. 2002. On the mystery of capital and the myths of Hernando de Soto. What difference does legal title make? International Development Planning Review, Volume 24, 1-19.

4. Wallace, J. and Williamson, I.P., 2006. Building land markets. Journal of Land Use

Policy, Volume 23(2), 123-135.

Vietnamese Legal Documents

1. Government Decree $17 / 1999 /$ ND-CP $\left(29^{\text {th }}\right.$ March 1999) on procedures for exchange, transfer, leasing, sub-leasing and bequeathing land use rights and using land use rights as collateral or capital contribution.

2. Government Decree $176 / 1999 /$ ND-CP $\left(21^{\text {st }}\right.$ December 1999$)$ on stamp duty.

3. Government Decree $19 / 2000 /$ ND-CP ( $8^{\text {th }}$ June 2000$)$, regulating detailed implementation of the Law on Land Use Right Transfer Tax and the Amended Articles of the Law on Land Use Right Transfer Tax.

4. Government Decree 38/2000/ND-CP (2 $3^{\text {rd }}$ August 2000) on collection of land use levies.

5. Government Decree $79 / 2001 /$ ND-CP ( $1^{\text {st }}$ November 2001) amending some articles of Government Decree $17 / 1999 /$ ND-CP $\left(29^{\text {th }}\right.$ March 1999$)$ on procedures for exchange, transfer, leasing, sub-leasing and bequeathing land use rights and using land use rights as collateral or capital contribution.

6. General Department of Land Administration Circular 1990/2001/TT-TCDC $\left(30^{\text {th }}\right.$ November 2001) guiding land registration, cadastral records and issue of land use right certificates.

7. Ministry of Finance Circular 93/2002/TT-BTC (21 ${ }^{\text {st }}$ October 2002) deciding on collection, payment and management of cadastral fees.

8. Land Law $13 / 2003 / \mathrm{QH} 11$ (26 $6^{\text {th }}$ November 2003). 


\section{University Library}

\section{- M M N E R VA A gateway to Melbourne's research publications}

Minerva Access is the Institutional Repository of The University of Melbourne

Author/s:

Smith, W;Williamson, I;Burns, A;Chung, TK;Ha, NTV;Quyen, HX

Title:

The impact of land market processes on the poor in rural Vietnam

Date:

2007-01-01

Citation:

Smith, W., Williamson, I., Burns, A., Chung, T. K., Ha, N. T. V. \& Quyen, H. X. (2007). The impact of land market processes on the poor in rural Vietnam. SURVEY REVIEW, 39 (303), pp.3-20. https://doi.org/10.1179/003962607X164952.

Publication Status:

Published

Persistent Link:

http://hdl.handle.net/11343/34931 